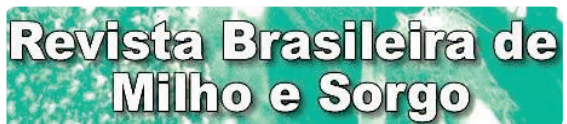

Brazilian Journal of Maize and Sorghum

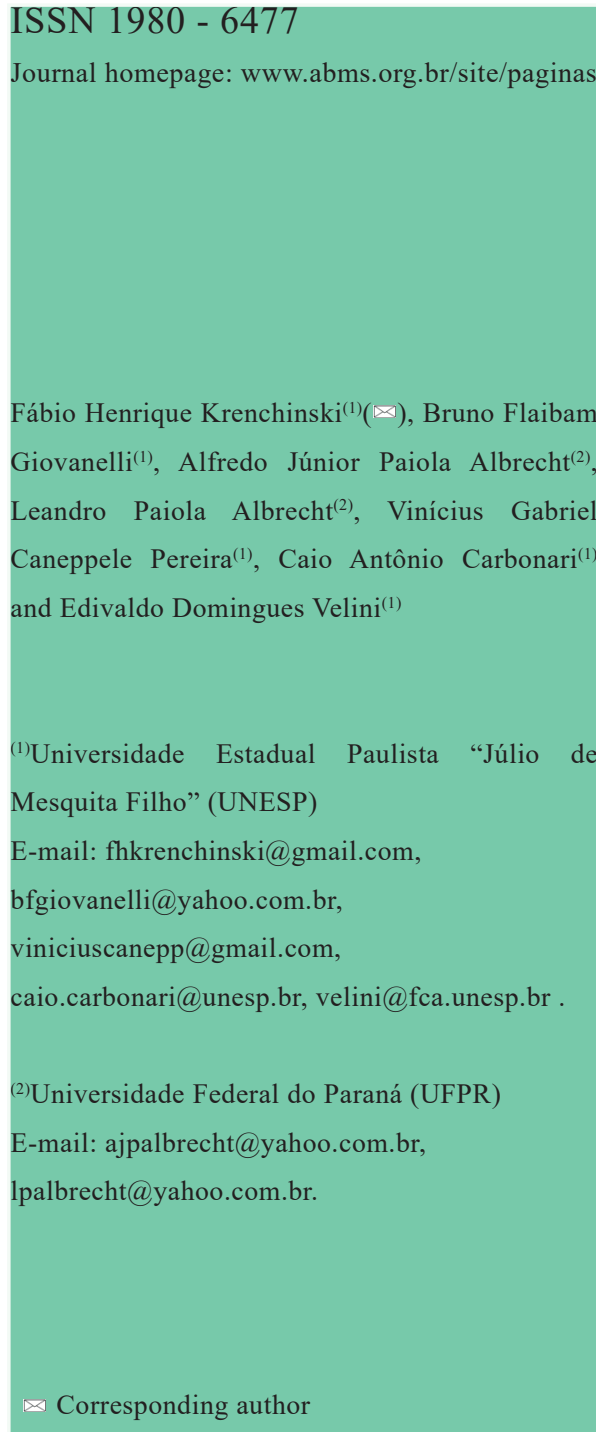

How to cite

KRENCHINSKI, F. H.; GIOVANELLI, B. F. ALBRECHT, A. J. P.; ALBRECHT, L. P.; PEREIRA, V. G. C.; CARBONARI, C. A. VELINI, E. D. Are glyphosate and glufosinateammonium totally selective for transgenic maize containing the cp4-epsps and pat genes?. Revista Brasileira de Milho e Sorgo, v. 19, e1154, 2020.

\section{ARE GLYPHOSATE AND GLUFOSINATE- AMMONIUM TOTALLY SELECTIVE FOR TRANSGENIC MAIZE CONTAINING THE CP4-EPSPS AND PAT GENES?}

\begin{abstract}
To achieve high crop yields, an advanced weed management program is required. Maize with cp4-epsps and pat genes is tolerant to glyphosate and glufosinate-ammonium herbicides and has been a tool used for weed control. However, there is a demand for new studies to assess how tolerant it is and to avoid yield losses. The objective of this study was to assess the selectivity of the 2B810PW hybrid, which has the cp4-epsps and pat genes, subjected to applications of glyphosate (gly) and glufosinateammonium (glu), both isolated and combined, at two different rates, during three crop years, in two municipalities in Paraná state. A randomized block design, with four replications, was used. Some measured variables, such as plant height, showed few differences between crop years and locations, while others, like percentage of seed germination and yield, showed no differences $(\mathrm{P} \leq 0.05)$. This demonstrates that the hybrid is resistant to the application of glufosinate-ammonium and glyphosate herbicides, isolated or combined, and these molecules can provide more options for weed control in crops of maize containing the cp4-epsps and pat genes.
\end{abstract}

Keywords: Zea mays, post-emergence, tank mixture, tolerance.

\section{GLYPHOSATE E AMÔNIO GLUFOSINATO SÃO TOTALMENTE SELETIVOS PARA MILHO TRANSGÊNICO CONTENDO OS GENES CP4-EPSPS E PAT?}

Resumo - Para alcançar altos rendimentos, é necessário um programa avançado de manejo de plantas daninhas. O milho com os genes cp4-epsps e pat é tolerante aos herbicidas glyphosate e amônio glufosinato e tem sido uma ferramenta usada para o controle de plantas daninhas, porém há uma demanda por novos estudos a este respeito, avaliando a sua resistência e evitandose perdas de rendimento. O objetivo deste estudo foi testar a seletividade do híbrido 2B810PW, que possui os genes cp4-epsps e pat, submetido a aplicações de glyphosate (gly) e amônio glufosinato (glu), tanto isolados como em mistura, em duas doses, durante três safras, e em dois municípios do estado do Paraná. O delineamento experimental utilizado foi em blocos ao acaso com quatro repetições. Algumas variáveis mensuradas, como altura de plantas, mostraram poucas diferenças entre as safras e locais, mas outras como porcentagem de germinação das sementes e produtividade, não apresentaram diferença $(\mathrm{P} \leq 0,05)$. Isso demonstra que o híbrido é resistente à aplicação dos herbicidas amônio glufosinato e glyphosate, isolados ou em mistura, e essas moléculas podem fornecer mais opções de controle de plantas daninhas na cultura do milho contendo os genes cp4-epsps e pat.

Palavras-chave: Zea mays, pós-emergência, mistura de tanque, tolerância. 
Maize (Zea mays L.) is a crop of great international importance, being one of the major food crops cultivated worldwide due to its high energy value and relatively low cost. Brazilian maize production is considerable, around 100.9 million tonnes, and the Paraná state is the second largest maize producer in the country, with over 14 million tonnes in 2019/2020 (CONAB, 2020). In this context, transgenic technologies, either for tolerance to lepidopteran insects or as herbicides, have been increasingly used, with $88.4 \%$ of transgenic maize being grown and consumed in the country (CIB,2017a). One of the existing technologies is Roundup Ready $2^{\circledR}$ (RR2), which provides tolerance to glyphosate and was approved for use in some crops in Brazil in 2008 (CIB, 2017b). This is possible due to the presence of the cp4-epsps enzyme, which is insensitive to glyphosate, obtained from Agrobacterium sp (Dill, 2005).

The pat gene is responsible for the phosphinothricin acetyltransferase enzyme, produced by the Streptomyces viridochromogenes bacterium, which transforms the glufosinate into n-acetyl-glufosinate, a compound that is not toxic to the plants (Herouet et al., 2005). However, glufosinate-resistant maize hybrids present different resistance levels (Krenchinski et al., 2018a), making it difficult to recommend the use of this herbicide.

There are 50 glyphosate-resistant weed species across the world, and nine of these plants are also present in Brazil, some of them having multiple resistance. The main ones are: Conyza spp, Lolium spp, Digitaria insularis, and more recently Euphorbia heterophylla (Heap, 2020; Adegas et al., 2020). As a result, the combination of herbicides has been a very common strategy in integrated weed management, thus being possible to mitigate or delay the emergence of resistant biotypes and provide an alternative control option for resistant biotypes (Norsworthy et al., 2012). Glyphosate mixed with glufosinate is a practice that has been employed in weed control due to the possibility of using it in postemergence of transgenic maize, either in tank mixture or in sequential applications.

Weed control is essential to crop production, but the study about the safe use of herbicides in the crop is also important. The herbicide-crop interaction is not stable, depending on various factors such as dosage and environmental conditions, as well as gene expression alteration and plant enzymatic activity. The cultivation of maize with the pat and cp4-epsps genes is a practice that is relatively recent in the country and, due to that reason, there are few studies and many questions about the possible effects of glufosinate used either alone or combined with glyphosate.

Therefore, the aim of this study was to evaluate the possible effects of glyphosate and glufosinate, used alone or in mixture, at different dosages, in a maize hybrid that presents the pat and cp4-epsps genes. 


\section{Material and Methods}

The present study consisted of five experiments in randomized block design with four replications. The plots contained six rows, with six-meter length and spacing of $0.45 \mathrm{~m}$. The four central rows were used for data collection up to one meter from each plot end.

All the experiments were carried out in the field, in Paraná state, Brazil, being three of them in the municipality of Palotina $\left(24.17^{\circ} \mathrm{S}, 53.50^{\circ} \mathrm{W}\right)$ during the 2014/2015, 2015, and 2015/2016 crop seasons, and the others in the municipality of Marechal Cândido Rondon $\left(24.33^{\circ} \mathrm{S}, 54.03^{\circ} \mathrm{W}\right)$ during the first crop season of 2014 and second crop season of 2015. The treatments consisted of glyphosate and glufosinate, isolated or combined, and a nontreated control. The treatments are described in Table 1.

In all experiments, the material used was the 2B810PW hybrid (Dow AgroSciences), which is resistant to lepidoptera insects and tolerant to glyphosate (cp4-epsps gene) and glufosinate (pat gene) herbicides, being considered a material of higher investment (Dow AgroSciences, 2016) that is largely cultivated in Brazil.

According to Köppen's classification, the predominant climate in the regions of the experiment is $\mathrm{Cfa}$ - mesothermal humid subtropical, with warm, rainy summer and cold winter, but without severe frosts. The altitude is around 285 meters, and the precipitation and temperatures are described in Figure 1.

Table 1. Treatments used in five experiments conducted in Palotina and Marechal Cândido Rondon - PR. Crop years: 2014/2015, 2015, and 2015/2016.

\section{Treatments}

Rate (g ha $\left.\mathbf{~ h}^{-1}\right)$

\section{Control}

Glyphosate*

Glufosinate

Glyphosate

Glufosinate

Glyphosate + glufosinate

Glyphosate + glufosinate

Glyphosate + glufosinate

Glyphosate + glufosinate
1,080

500

2,160

1,000

$1,080+500$

$2,160+500$

$1,080+1,000$

$2,160+1,000$

*: grams of acid equivalent per hectare 

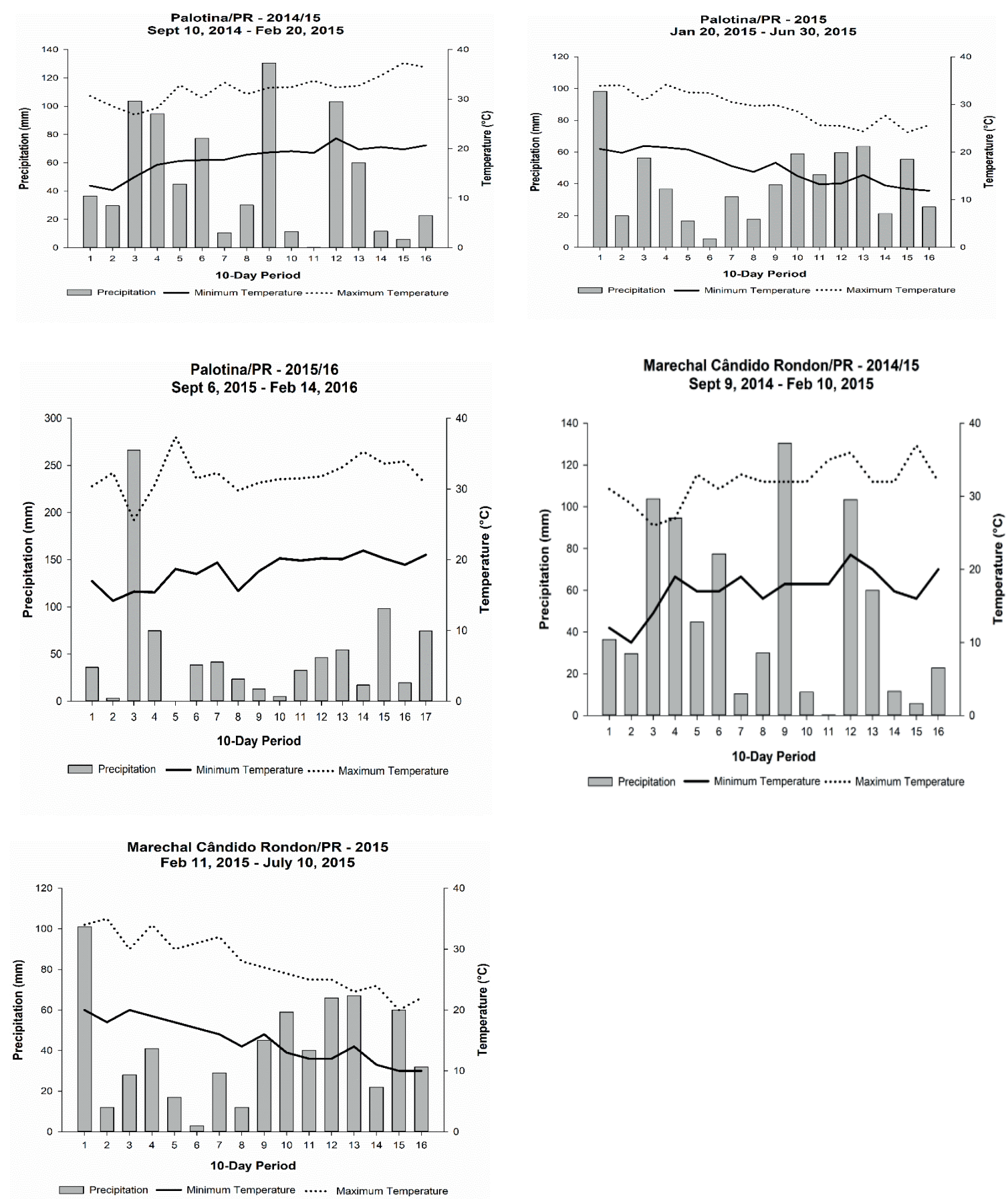

Figure 1. Representation of precipitation, minimum and maximum temperatures in Palotina and Marechal Cândido Rondon municipalities - Paraná state, Brazil, in 2014/15, 2015, and 2015/2016 crop seasons. Source: Sistema Meteorológico do Paraná (2016). 
The chemical and physical soil analyses were carried out prior to the planting of all experiments, in the layer from 0 to $20 \mathrm{~cm}$ depth. In Palotina, the $\mathrm{pH}$ and base saturation values were 5.80 and $68 \%$, respectively, with $68 \%$ of clay content. In Marechal Cândido Rondon, those values were 5.61 and $75 \%$, respectively, and $63 \%$ of clay content. The local soils are classified as Ferralsol.

Herbicides were applied at the V4 phenological stage, using a $\mathrm{CO}_{2}$-pressurized backpack sprayer, consisting of a six-nozzle boom fitted with six XR 110.02 flat-fan nozzles, calibrated to deliver a spray volume of $200 \mathrm{~L} \mathrm{ha}^{-1}$ at $200 \mathrm{kPa}$ of pressure.

The application conditions in the 2014/2015 crop season were the following: temperatures of 34.7 and $28^{\circ} \mathrm{C}$, relative air humidity of 58 and $54 \%$, and wind speed of 2.1 and $1.12 \mathrm{~km} \mathrm{~h}^{-1}$, respectively, for Palotina and Marechal Cândido Rondon. In the second 2015 crop, the conditions were the following: temperatures of 28.1 and $29.7^{\circ} \mathrm{C}$, relative air humidity of 68 and $59.4 \%$, and wind speed of 1.1 and $1.3 \mathrm{~km} \mathrm{~h}^{-1}$, respectively, for Palotina and Marechal Cândido Rondon. In the 2015/2016 crop season in Palotina, the climate conditions were: $31.4^{\circ} \mathrm{C}$ temperature, $54 \%$ of air humidity, and $1.4 \mathrm{~km} \mathrm{~h}^{-1}$ of wind speed.

Experimental plots were kept free from weeds by manual weeding throughout the cropgrowing period. Planting and harvesting times followed the schedule recommended for the western state region.

At the V8 phenological stage, an electronic chlorophyll content meter (ClorofiLOG, Falker) was used to determine the total chlorophyll content. The device uses the Falker chlorophyll index (FCI), which presents a high correlation with the chlorophyll contents obtained in laboratory (Falker, 2009). The last developed plant leaf was measured, in eight plants per plot, and the average was calculated for those values.

The variables relating to crop agronomic performance were obtained during the R6 stage (physiological maturity), being the ear insertion height $(\mathrm{EIH})$ and plant height $(\mathrm{PH})$ of ten plants from the central area of each plot. For the two variables, the distance was measured from the soil surface up to the ear and tassel insertions, respectively.

At the end of the crop season, the maize ears were manually harvested and threshed in a thresher machine. Maize grain yield ( $\mathrm{kg}^{\mathrm{h}}{ }^{-}$ $\left.{ }^{1}\right)$ was calculated based on the weight of each plot, and the 100-grain weight (100-gW) was calculated based on four 100-grain samples per plot. For both variables, the values were adjusted to $13 \%$ moisture.

Then, to assess the seed quality, germination and vigor tests were conducted on the harvested material. For this purpose, an amount of fifty seeds per plot was wrapped in moistened paper towel and kept into a seed germinator at $25^{\circ} \mathrm{C}$. Afterwards, the germinated seeds were counted, with the first count being made four days after the test installation and the second count on the seventh day, respectively for vigor and germination testing (Brasil, 2009). 
Data were subjected to analysis of variance (ANOVA) and the means were compared by Tukey's test ( $\mathrm{P} \leq 0.05)$, according to Pimentel-Gomes and Garcia (2002), using the software Sisvar - version 5.6 (Sisvar DEX/ Federal University of Lavras - UFLA, Copyright 1992-2010). The minimum significant difference (MSD) and the coefficient of variation (CV\%) were calculated. Some differences could be found between the locations and crop seasons, through joint statistical analysis, and for this reason the data will be discussed separately.

\section{Results and Discussion}

The results indicate that there were no differences in the variables relating to ear insertion height and plant height for the assessed hybrid (Table 2). Although in the results obtained for the latter variable, in the 2015 crop season, in Marechal Cândido Rondon, the glyphosate + glufosinate treatment, at its highest rates, showed reduction of plant height and differed from the isolated herbicides and the control treatment, but it did not differ from the other mixtures.

However, this variation was observed only in the second crop year, when a period of low temperature prevailed, thus diminishing the thermal sum, which is crucial for maize development (Bergamaschi \& Matzenauer, 2014), with less recovery time from any herbicide injury. Vieira Júnior et al. (2015) studied glyphosate selectivity, either isolated or combined with atrazine (1,500), 2,4-D (241.8), bentazon (720), nicosulfuron (60), and tembotrione (100.8) herbicides, in maize post-emergence, and found no reduction in plant and ear insertion height.

There was no difference in regard to the total chlorophyll (Table 3), thus indicating that the herbicides are not affecting the photosynthetic apparatus and the technology is resistant to both ingredients, even as to glufosinate, which has a more rapid effect when compared to glyphosate and provides ammonia accumulation, resulting in chlorophyll electron transportation decrease for sensitive plants (Dayan \& Zaccaro, 2012).

In general, there was no difference regarding the 100-seed weight, except for the 2014/2015 crop season in Palotina, where glufosinate at 500 and $1,000 \mathrm{~g}$ differed from the glyphosate $(1,080)$ + glufosinate $(1,000)$ (Table 5). A lower 100-grain weight was observed for the glufosinate at 1,000 $\mathrm{g}$ applied alone, when compared to the other treatments, except for glyphosate at 1,080 $\mathrm{g}+$ glufosinate at $1,000 \mathrm{~g}$, but that did not differ from the control treatment. In contrast, Krenchinski et al. (2018b) obtained the highest 100-grain weight value, when compared to the control, in a treatment involving glyphosate $(1,080)$, atrazine $(2,000)$, and glufosinate (500) in tank mixture.

The treatments did not reduce the maize grain yield (Table 4). Burke et al. (2008) observed that glyphosate (840) or glufosinate (470) applied singly and sequentially did not influence maize yield. Armel et al. (2008) also demonstrated that early and late post-emergence applications of glufosinate (300) and mesotrione (70, 105 and 140) mixture did not reduce grain 


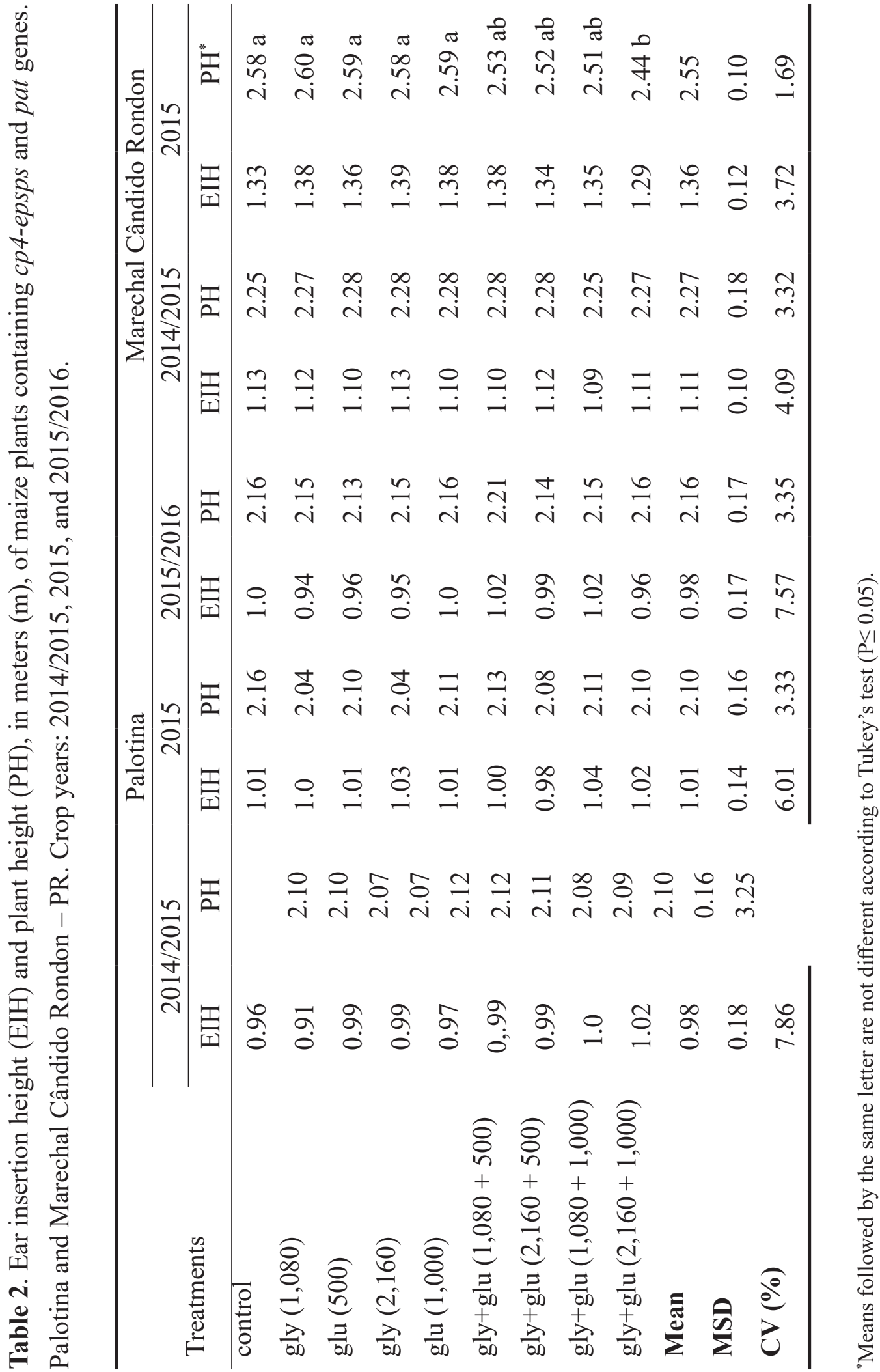




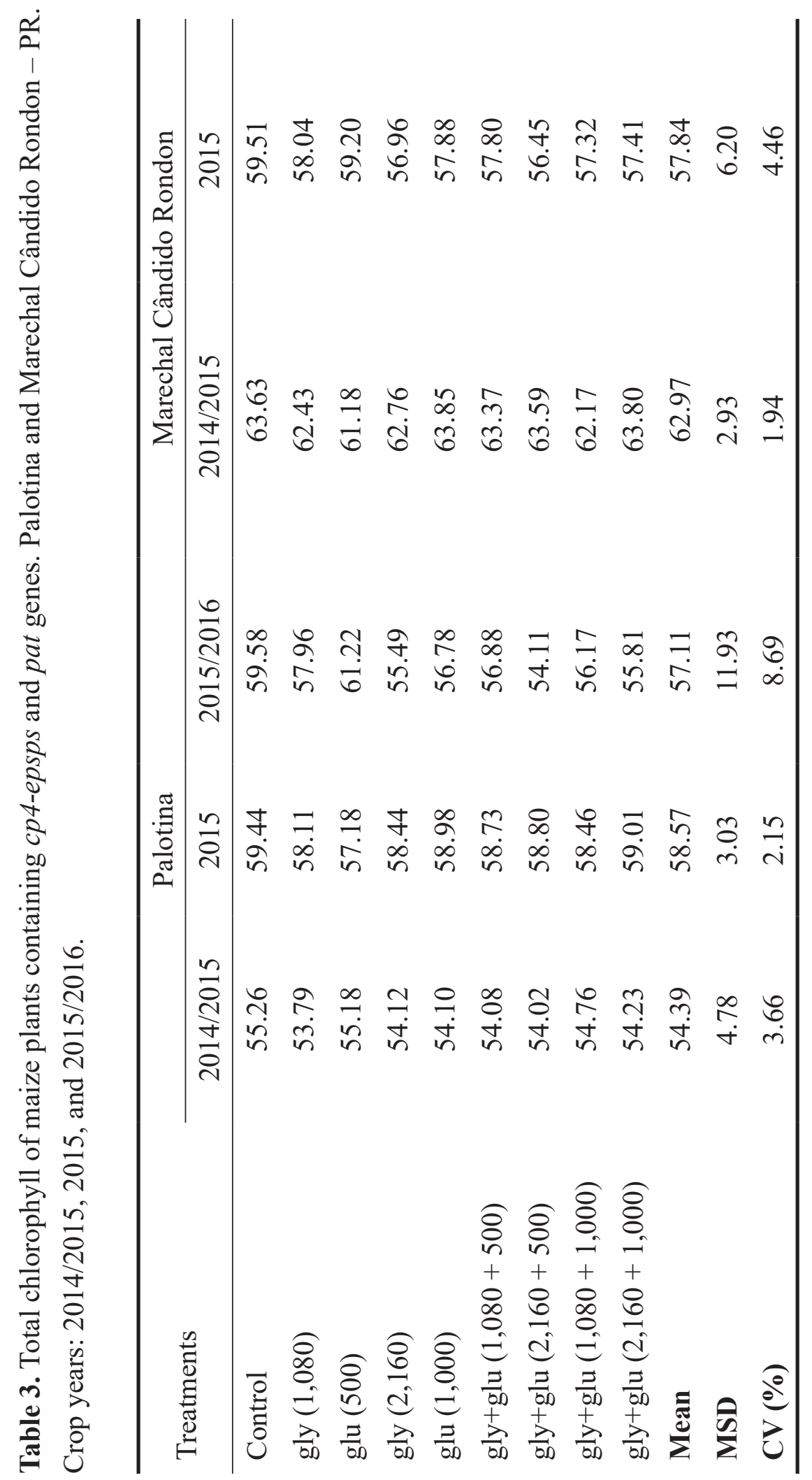




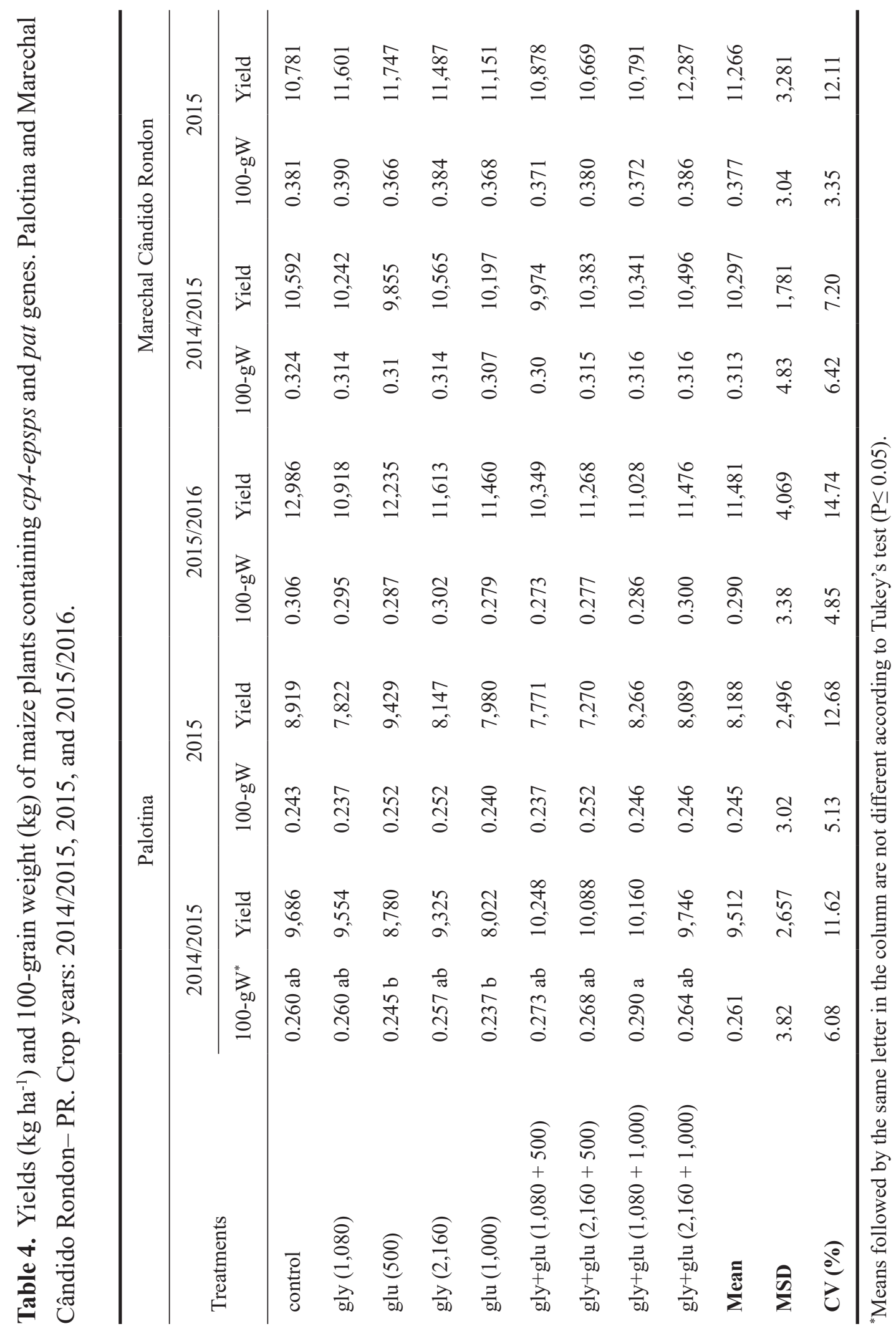




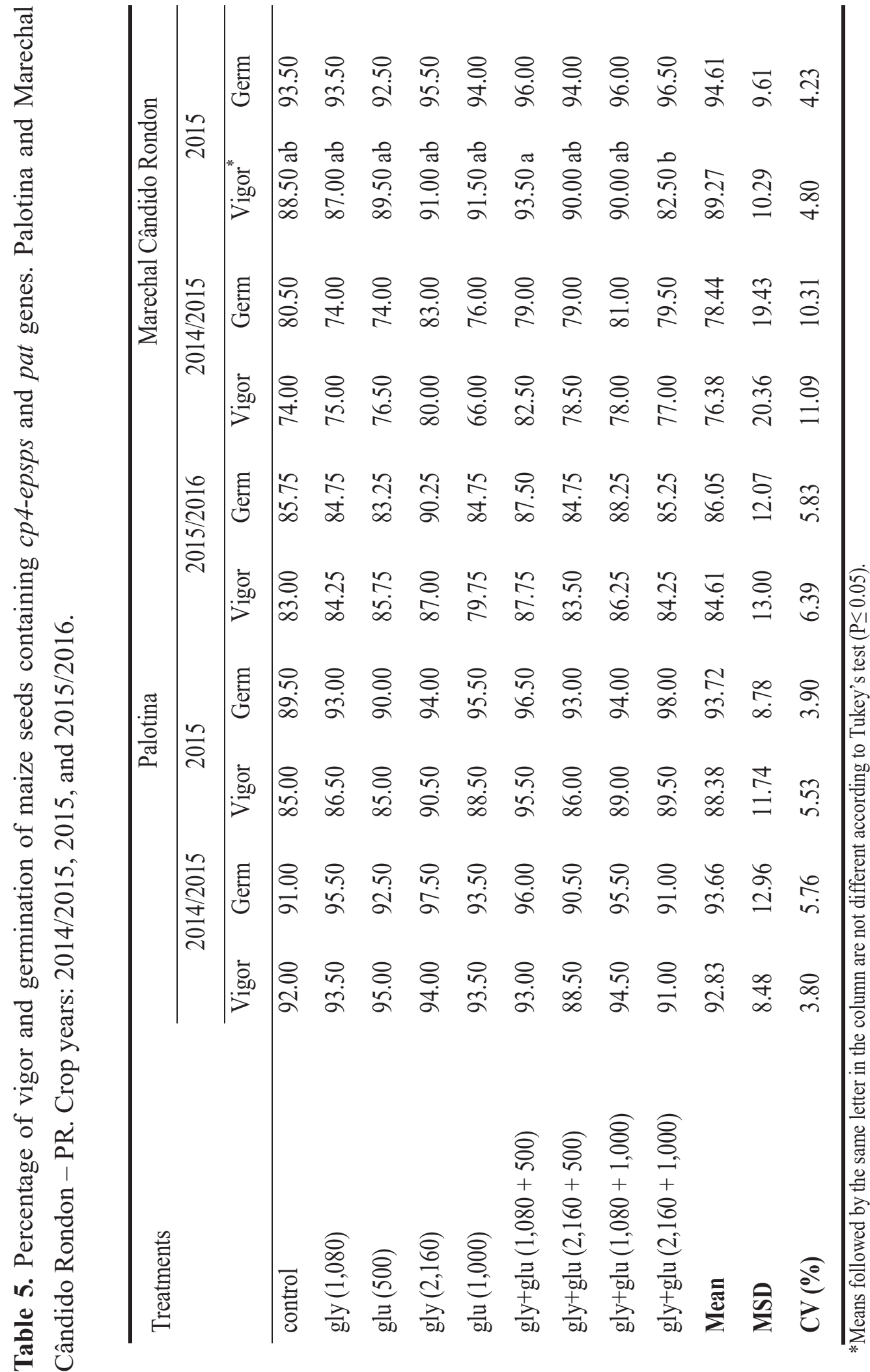


yield in maize crops. However, Krenchinski et al. (2018b) observed a yield decrease when combined applications of glufosinate, glyphosate, and atrazine were used, which act on different metabolic routes and, when combined, they can interfere with some production components such as yield and ear insertion height.

The variables relating to seed physiological performance (vigor and germination) were not affected by the herbicides (Table 5). The last treatment applied in Marechal Cândido Rondon, in the 2015 crop season, presented a lower seed vigor, but it did not differ from the control. Webster et al. (2003) concluded that glufosinate, when applied at different phenological stages of some herbicide-resistant rice varieties, in general did not affect variables such as vigor, germination and 100-grain weight either. However, Reddy et al. (2011) found increased protein levels, reduced oil and linoleic acid contents in soybean varieties resistant to glufosinate herbicides.

In non-resistant hybrids, possible glufosinate drifts may reduce crop yields in an average of 11 to $13 \%$ between late and early postemergence applications, respectively (Ellis et al., 2003). Glufosinate-resistant maize may resist up to three times the recommended dosage (Peters et al., 1999). Thus, this herbicide becomes an important additional tool to integrated weed management and the results obtained in this research are important for an adequate positioning regarding the use of glufosinate.

\section{Conclusions}

In the present study, the maize hybrid 2B810 PW (cp4-epsps and pat genes) showed a high tolerance to post-emergence application of glyphosate and glufosinate, either isolated or combined, at the rates tested.

\section{Acknowledgements}

Research supported by the Federal University of Paraná, Paraná state, Brazil.

\section{References}

ACOMPANHAMENTO da Safra Brasileira [de] Grãos: safra 2019/2020: nono levantamento. Brasília, DF: Conab, 2020. v. 7, n. 9, p. 41-47.

ADEGAS, F. S.; GAZZIERO, D. L. P.; OLIVEIRA JÚNIOR, R. S. de; MENDES, R. R.; RODRIGUES, L. J. Euphorbia heterophylla: um novo caso de resistência ao glifosato no Brasil. Londrina: Embrapa Soja, 2020. 5 p. (Embrapa Soja. Comunicado Técnico, 98).

ARMEL, G. R.; RICHARDSON, R. J.; WILSON, H. P.; HINES, T. E. Mesotrione and glufosinate in glufosinate-resistant corn. Weed Technology, v. 22 , n. 4 , p. 591-596, 2008. DOI: 10.1614/WT08-048.1.

BERGAMASCHI, H.; MATZENAUER, R. O 
milho e o clima. Porto Alegre: Ascar, 2014.

BRASIL. Ministério da Agricultura, Pecuária, e Abastecimento. Secretaria de Defesa Agropecuária. Regras para análise de sementes. Brasília, DF, 2009. Available in: $<$ http://www.agricultura.gov.br/assuntos/ insumos-agropecuarios/arquivos-publicacoesinsumos/2946_regras_analise_sementes.pdf $>$. Access in: 13. Sept. 2019.

BURKE, I. C.; THOMAS, W. E.; ALLEN, J. R.; COLLINS, J.; WILCUT, J. W. A comparison of weed control in herbicide-resistant, herbicidetolerant, and conventional corn. Weed Technology v. 22, n. 4, p. 571-579, 2008. DOI: 10.1614/WT-07-184.1.

CAVALIERI, S. D. Influência do glyphosate em cultivares de soja RR e do herbicida nicosulfuron aplicado em híbridos de milhopipoca em três estádios de desenvolvimento. 2010. 67 p. Tese (Doutorado) - Universidade Estadual Paulista "Júlio de Mesquita Filho", Botucatu, 2010.

CONSELHO DE INFORMAÇÕES SOBRE BIOTECNOLOGIA. Adoção de transgênicos no Brasil em 2016. 2017a. Available in: <http:// cib.org.br/adocao-de-transgenicos-no-brasilem-2016/>. Access in: 24 May 2019.

CONSELHO DE INFORMAÇÕES SOBRE BIOTECNOLOGIA. Quantos produtos transgênicos estão aprovados hoje no País? 2017b. Available in: <http://cib.org.br/estudose-artigos/perspectivas-para-a-cultura-domilho-no-brasil/>. Access in: 4 May 2019.

DAYAN, F. E.; ZACCARO, M. L. de M. Chlorophyll fluorescence as a marker for herbicide mechanisms of action. Pesticide Biochemistry and Physiology, v. 102, n. 3, p. 189-197, 2012. DOI: 10.1016/j. pestbp.2012.01.005.

DILL, G. M. Glyphosate-resistant crops: history, status and future. Pest Management Science, v. 61 , n. 3, p. 219-224, 2005. DOI: 10.1002/ps. 1008 .

DOW AGROSCIENCES. Guia de sementes. Indianópolis, 2016. Available in: <https:// docplayer.com.br/34595170-Guia-desementes-2016.html>. Access in: 21 May 2019.

ELLIS, J. M.; GRIFFIN, J. L.; LINSCOMBE, S. D.; WEBSTER, E. P. Rice (Oryza sativa) and corn (Zea mays L.) response to simulated drift of glyphosate and glufosinate. Weed Technology. v. 17, n. 3, p. 452-460, 2003. DOI: 10.1614/WT01-110.

FALKER. ClorofiLOG: medidor eletrônico de teor de clorofila. Porto Alegre, 2009. Available in: $\quad<$ https://www.falker.com.br/produtoclorofilog-medidor-clorofila.php>. Access in: 24 May 2019. 


\section{HEAP, I. The International Survey of} Herbicide Resistant Weed Database. Available in: <http://www.weedscience.org $>$. Access in: 17 June 2020.

HEROUET,C.; ESDAILE, D. J.; MALLYON, B. A.; DEBRUYNE, E.; SCHULZ, A.; CURRIER, T.; HENDRICKS, K.; VAN DER KLIS, R. J.; DOMINIQUE, R. Safety evaluation of the phosphinothricin acetyltransferase proteins encoded by the PAT and bar sequences that confer tolerance to glufosinate-ammonium herbicide in transgenic plants. Regulatory Toxicology and Pharmacology. v. 41, n. 2, p. 134-149, 2005. DOI: 10.1016/j.yrtph.2004.11.002.

KRENCHINSKI, F. H.; ALBRECHT, A J. P.; CESCO, V. J. S.; RODRIGUES, D. M.; PEREIRA, V. G. C.; ALBRECHT, L. P.; VICTÓRIA FILHO, R. Post-emergent applications of isolated and combined herbicides on corn culture with CP4-EPSPS and PAT genes. Crop Protection, v. 106, p. 156-162, $2018 \mathrm{a}$. DOI: 10.1016/j.cropro.2017.11.016

KRENCHINSKI， F. H.; CARBONARI， C. A.; CESCO, V. J. S.; ALBRECHT, A. J. P.; ARCURI, M. D. L. C.; MAIA, I. G.; VELINI, E. D. Glufosinate resistance level is proportional to phosphinothricin acetyltransferase gene expression in glufosinate-resistant maize. Journal Agriculture and Food Chemistry, v. 66, n. 48, p. 12641-12650, 2018b. DOI: 10.1021/ acs.jafc. 8 b04823.
MARKWELL, J.; OSTERMAN, J.; MITCHELL, J.; JENNIFER, L. Calibration of the Minolta SPAD-502 leaf chlorophyll meter. Photosynthesis Research, v. 46, n. 3, p. 467472, 1995. DOI: 10.1007/BF00032301.

MÔRO, G. V.; FRITSCHE-NETO, R. Importância e usos do milho no Brasil. In: BORÉM, A.; GALVÃO, J. C. C.; PIMENTEL, M. A. (Ed.). Milho: do plantio à colheita. Viçosa, MG: UFV, 2015. p. 9-24.

NORSWORTHY, J. K. Repeated sublethal rates of glyphosate lead to decreased sensitivity in Palmer amaranth. Crop Management, v. 11, n. 1, p. 1-6, 2012. DOI: 10.1094/cm-2012-0403-01rs.

PETERS, D. A.; GRIFFIN, J. L.; ELLIS, J. M.; BOND, J. A.; GODLEY, J. L. Corn tolerance and weed control with Liberty Link and Roundup Ready programs. Proceedings Southern Weed Science Society, v. 2, n. 52, p. 219-220, 1999.

PIMENTEL-GOMES， F.; GARCIA， C. H. Estatística aplicada a experimentos agronômicos e florestais: exposição com exemplos e orientações para uso de aplicativos. Piracicaba: FEALQ, 2002. 309 p.

REDDY, K. N.; ZABLOTOWITZ, R. M.; BELlALOUI, N.; DING, W. Glufosinate effects on nitrogen nutrition, growth, yield, and seed composition in glufosinate-resistant and 
glufosinate-sensitive soybean. International VIEIRA JÚNIOR, N. S.; JAKELAITIS, Journal of Agronomy, v. 2011, article ID109280， A.; CARDOSO， I. S.; REZENDE， P. N.; 2011. DOI: $10.1155 / 2011 / 109280$. MORAES, N. C.; ARAÙJO, V. T.; TAVARES, T. J. Associação de herbicidas aplicados em pósSISTEMA METEOROLÓGICO DO PARANÁ. Tempo: dados da estacão - Palotina. Disponível em: $\quad<$ http://www.simepar.br/prognozweb/ simepar/home>. Acesso em: 10 Set. 2016. emergência na cultura do milho. Global Science and Technology, v. 8, n. 1, p. 1-8, 2015. DOI: 10.14688/1984-3801/gst.v8n1p1-8.

WEBSTER, E. P.; LANCLOS, D. Y.; ZHANG, W. Influence of glufosinate on seed weight, seed germination, and seedling vigor of glufosinateresistant rice. Weed Technology, v. 17, n. 1, p. 51-54, 2003. DOI: 10.1614/0890-037X(2003)01 7[0051:IOGOSW]2.0.CO;2. 